Jpn. J. Med. Mycol.

Vol. 28, 262-269, 1987

ISSN $0583-0516$

\title{
Protection Activity Induced by the Bacterial Vaccine, Heat-Killed Clostridium butyricum Against Candida albicans Infections in Mice
}

\author{
Chen Hour-Young ${ }^{1}$, Satoru Kaneda ${ }^{1}$, Yuzuru Mikami1 ${ }^{1}$ Tadashi Arai ${ }^{*}$, \\ Kazuei Igarashi², Masayoshi Saito ${ }^{3}$, Takeyoshi Miyoshi ${ }^{3}$ \\ and Akira Fuse ${ }^{4}$ \\ Departments of Experimental Chemotherapy ${ }^{1}$, Research Center for Pathogenic Fungi and \\ Microbial Toxicoses, and Departments of Radiology ${ }^{3}$ and Microbiology ${ }^{4}$, School of Medicine, \\ Chiba University, 1-8-1, Inohana, Chiba 280 \\ Department of Clinical Biochemistry ${ }^{2}$, Faculty of Pharmaceutical Sciences, Chiba University, \\ 1-13, Yayoi-cho, Chiba 260, Japan
}

[Received for Publication: April 2, 1987]

\begin{abstract}
The bacterial vaccine, heat-killed Clostridium butyricum exhibits various immunomodulating activities including a strong protection activity against Candida albicans infection in mice. The analyses of immunomodulating activities induced by the vaccine showed that the vaccine stimulated macrophage and natural killer cell activity. Stimulation of delayed type hypersensitivity, IgM antibody formation and induction of $\gamma$-type interferon were observed. The vaccine was also mitogenic for B-cell lymphocytes. Among these immunomodulating activities, interferon was considered to be one of the important factors in the manifestation of in vivo anticandida activity. Futher studies using recombinant interferon (IFN $\alpha-\mathrm{A} / \mathrm{D}$ type interferon) confirmed the active role of interferon in the manifestation of the protection. The interferon production by the vaccine was also found to be dependent on the mouse strain used and was most active in DDY mice.
\end{abstract}

Key words: Clostridium butyricum, vaccine, anti-candida activity, immunomodulating activity, interferon

A butyric acid bacterium Clostridium butyricum MII 588 has been used clinically to prevent distrubances of microbial flora in intestine in Japan ${ }^{11}$. It has also been reported that oral administration of the bacterial spore improves clinical symptoms, such as diarrhea, constipation and abdominal distension ${ }^{2}$. During our studies on the mechanism of $C$. butyricum anti-putrefactive action, we found that the bacterium showed a strong antimetastatic activity against B16-melanoma in mice, although it showed no direct cytotoxic effect on various tumor cell lines, such as L1210 and EL 4 leukemias (unpublished data by Chen et al.). These data indicate that the antitumor activity induced by the bacterium is host mediated and that the bacterium itself may induce various immunomodulating activities.

In vivo protection activity against various microbial infections by BRMs (biological response modifiers), PSK, MDP, LPS and OK-432 (Kaneda et al., manuscript in

*To whom inquires should be addressed. preparation) has been reported. Since systemic candidiasis is a significant complication of immunodeficiency syndromes, surgical procedures, and immunosuppressive medical therapies ${ }^{3)}$, we are interested in the immunomodulating activities of the vaccine.

In this paper, we report various immunomodulating activities induced by the bacterium including protection activity against Candida albicans infection in mice. We also discuss the possible effectors which play an important role in the manifestation of the anti-candida activities.

\section{METERIALS AND METHODS}

Animals: Male Balb/c, $\mathrm{BDF}_{1}, \mathrm{C} 3 \mathrm{H} / \mathrm{He}, \mathrm{DBA} / 2$, DDY and ICR mice, 4 to 10 weeks old were purchased from Shizuoka Laboratory Animal Corporation Ltd., Hamamatsu, Japan and used throughout the study. For systemic Candida infection, 4 weeks old DDY mice were used. 
Preparation of $\mathrm{CB}$ vaccine: Clostridium butyricum MII 588 was cultured for $24 \mathrm{hr}$ at $37^{\circ} \mathrm{C}$ in PYG medium ${ }^{4)}$. C. butyricum was then harvested, washed several times with saline and suspended in saline. The cell suspension was heated for $1 \mathrm{hr}$ at $100^{\circ} \mathrm{C}$ and lyophilized. $\mathrm{CB}$, a lyophilized whole cell preparation of the $C$. butyricum MII 588 cells, was reconstituted with saline to give 20 $\mathrm{mg} / \mathrm{ml}$ of the cells. MCB (methanol extract of $\mathrm{CB}$ ) fraction was prepared as follows: lyophilized whole cell preparation of CB (160 g) was extracted with methanol and the solvent extract was evaporated in vacuo to dryness. The dried residue was dissolved in a small amount of methanol and chromatographed on Sephadex LH-20 (Pharmacia, Sweden) column with methanol. The fast moving pale yellowish colored fraction was combined and evaporated to dryness. The dried residues thus obatined $(2 \mathrm{~g})$ were used as MCB fractions.

Media and cell lines: RPMI 1640 medium (Nissui Seiyaku Co., Ltd., Tokyo) was supplemented with $10 \%$ heat-inactivated fetal calf serum (Flow Laboratories, McLean, Virginia, USA), $40 \mu \mathrm{g} / \mathrm{ml}$ of gentamicin, and 3 $\mu \mathrm{g} / \mathrm{ml}$ of glutamine. Eagle's minimum essential medium (MEM, Nissui Seiyaku) supplemented with 10\% FCS, 60 $\mu \mathrm{g} / \mathrm{ml}$ of kanamycin and $3 \mu \mathrm{g} / \mathrm{ml}$ of glutamine was also used. All cell cultures were carried out at $37^{\circ} \mathrm{C}$ in a humidified atmosphere with $5 \% \mathrm{CO}_{2}$. YAC-1 lymphoma cells of $\mathrm{A} / \mathrm{Sn}$ origin were maintained in RPMI 1640 medium. EL-4 leukemic cells were maintained in the peritoneal cavities of C57BL/ 6 mice by weekly sequential transplantation. Mouse fibroblast cell line L929 was grown in MEM.

Systemic infection with $C$. albicans in mice: A highly virulent $C$. albicans IFM 40009 (ATCC 48130) strain was grown at $37^{\circ} \mathrm{C}$ on Sabouraud dextrose agar (SDA, Difco Lab., Detroit, USA) for $18 \mathrm{hr}$. Mice were infected with an intravenous injection of $5 \times 10^{5}$ blastospores of C. albicans IFM 40009.

Effect of CB, MCB or interferon (IFN) on C. albicans infection: In vivo anti-candida activity was evaluated by the comparison of survival time with that of saline treated controls. Before $C$. albicans infection, mice were given an intraperitoneal injection of $\mathrm{CB}$ on days $-3,-2$, and -1 . C. albicans cells $\left(5 \times 10^{5}\right.$ cells $)$ in 0.2 $\mathrm{ml}$ of saline were inoculated into the tail vein of mice on day 0 .

In cases of recombinant IFN $\alpha-\mathrm{A} / \mathrm{D}$ (lot. no. RG-A/D02) (kindly given by Nippon Roche, Co., Ltd., Japan), $1 \times$ $10^{4} \mathrm{U} /$ day was administered intravenously on day -1 .

Mitogenicity: Mitogenicity was determined by a slight modification of the method described by Kumazawa et $a l .^{5)}$. Briefly, spleen and thymus cell suspensions were prepared by gentle teasing, passed through a 200-gauge stainless steel sieve, and centrifuged. The packed cells were treated with ammonium chloride tris buffer to lyse red cells, and washed three times with MEM. The cells were cultured at a density of $1 \times 10^{6}$ cells $/ \mathrm{ml}$ in a total volume of $0.2 \mathrm{ml}$ including appropriate concentrations of $\mathrm{CB}$. After incubation at $37^{\circ} \mathrm{C}$ in a humidified atmosphere with $5 \% \mathrm{CO}_{2},{ }^{3} \mathrm{H}-$ thymidine $(1 \mu \mathrm{Ci})$ was added to each culture and further incubated for $4 \mathrm{hr}$. Cells were collected on glass fiber filters using a multiple cell harvester. Incorporation of ${ }^{3} \mathrm{H}$-thymidine as determined by liquid scintillation counter. Lipopolysaccharide (LPS, Difco) and concanavalin A (Wako Pure Chemical Ind. Ltd., Japan) were used as controls.

Delayed-type footpad reaction: This reaction was determined by the method described by Yoshikai et al. ${ }^{6}$. Ten-week old DDY mice were injected intraperitoneally with $2 \times 10^{6}$ sheep red blood cells (SRBC) and at the same time with various doses of $\mathrm{CB}$ by the same route. Four days later $1 \times 10^{8} \mathrm{SRBC}$ was given and $24 \mathrm{hr}$ footpad swelling was measured.

PFC assay: Numbers of hemolytic plaque-forming cells (PFC) in the spleen were determined to study the effect of $\mathrm{CB}$ on antibody formation according to the method of Cunningham and Szenberg ${ }^{7}$.

IFN assay and its induction by $\mathrm{CB}$ treatment: Mice were intraperitoneally given $\mathrm{CB}$ in $0.2 \mathrm{ml}$ of saline. At intervals, groups of 5 mice were bled by cardiac puncture, the blood was pooled and sera were separated by centrifugation. The sera were frozen at $-80^{\circ} \mathrm{C}$ until testing for IFN contents $^{8)}$. OK-432 (0.5 KE/mouse), a streptococcal whole cell preparation (Chugai Seiyaku Co. Ltd., Tokyo) was used as control IFN producer. The antiviral activity of the mouse serum (IFN titer) was determined using the plaque reduction method on mouse L-929 monolayer cell cultures by the method described previously ${ }^{9}$. IFN titer was expressed in units per milliliter as the reciprocal of the dilution that reduced cytopathic effect (CPE) by $50 \%$ as compared with the virus control.

Neutralization test: Anti-IFN $(\alpha / \beta)$ serum, a rabbit antiserum against mouse $L$-cell IFN was purchased from Lee Biomolecular Research, San diego, CA, U.S.A. Neutralization tests ${ }^{10)}$ were performed by the method described by Yamamoto and Kawada ${ }^{11)}$.

Natural killer (NK) cell activity assay: The activity was determined by cytotoxic activity against YAC-1 target cells. Short term ${ }^{51} \mathrm{Cr}$-release assay of $\mathrm{NK}$ cell activity was performed with fresh murine spleen cells used as the effector cells. Briefly, YAC-1 target cells were labeled for $40 \mathrm{~min}$ at $37^{\circ} \mathrm{C}$ with $100 \mu \mathrm{Ci}$ of $\mathrm{Na}_{2}{ }^{51} \mathrm{CrO}_{4}{ }^{51}$. In all assays, $2 \times 10^{4}$ target cells in a volume of $100 \mu \mathrm{l}$ were seeded in roundbottom tissue culture plates (Costar). Appropriate concentrations of spleen cells in a $100 \mu \mathrm{l}$ volume were added. Radioactivity was counted in a gamma counter (LKB). The percent 
specific ${ }^{51} \mathrm{Cr}$-release was calculated according to the formula:

$$
\begin{aligned}
& \text { specific lysis }(\%)= \\
& \left(\text { experimental }{ }^{51} \mathrm{Cr} \text { release }-\right. \\
& \frac{\text { spontaneous }{ }^{51} \mathrm{Cr} \text { release) }}{\text { (maximum }{ }^{51} \mathrm{Cr} \text { release }-} \\
& \text { spontaneous }{ }^{51} \mathrm{Cr} \text { release) }
\end{aligned}
$$

The spontaneous ${ }^{51} \mathrm{Cr}$-release from target cells incubated in medium alone was less than $10 \%$ of the total ${ }^{51} \mathrm{Cr}$.

Macrophage activity: The activity was also determined by the cytostatic activity of macrophages against EL-4 leukemia. Macrophage fraction was prepared from peritoneal exudate cells (PEC) of $\mathrm{CB}(1 \mathrm{mg})$ treated mice by the plastic adhering method. The in vitro cytostatic activity of macrophages was determined using the ${ }^{3} \mathrm{H}$ thymidine incorporation inhibition method described by Kato et al. ${ }^{12}$ ). EL-4 leukemia cells were used as target cells. Results obtained as average counts per minute were expressed as percent incorporation calculated by the formula:

$$
\begin{aligned}
& {[\mathrm{cpm} \text { (tumor }+ \text { effector cell) }-} \\
& \frac{\mathrm{cpm}(\text { effector cell alone) }]}{\mathrm{cpm} \text { (tumor cell alone) }} \times 100(\%) .
\end{aligned}
$$

Phagocytic activity against opsonized SRBC: SRBC and anti-SRBC IgG were purchased from Nippon Bio-Test Laboratories, Tokyo and from Japan Immunoresearch Laboratories Co., Ltd., respectively. Assay method was the same as that of Kato et al. ${ }^{12)}$. The number of SRBC phagocytized by peritoneal macrophages was counted microscopically and phagocytic activity was also determined as the number of SRBC phagocytized per 100 macrophages.

Statisitical analysis: The difference between experimental and control groups was evaluated statistically with a student's $t$-test and the probability $(p)$ was calculated.

\section{RESULTS}

Protection induced by $\mathrm{CB}$ against systemic $C$. albicans infection in mice: When $C B$ was administered intraperitoneally to DDY mice as a premedication, i.e., for three consecutive days before intravenous infection with $C$. albicans, significant increase in survival time was observed at all doses of CB tested (Fig. 1). Optimum dose was around 0.5 to $1.0 \mathrm{mg} / \mathrm{mouse}$ and $40 \%$ of the group survived after 30 days. These results indicate that $\mathrm{CB}$ can induce strong host mediated anticandida activity. MCB, the methanol extract of $\mathrm{CB}$, was also found to be active against the infection. Seventy percent of the mice were still surviving after 30 days at the dose of $0.5 \mathrm{mg} / \mathrm{mouse}$ of MCB. These results indicate that active principles of $\mathrm{CB}$ were extractable by the solvent, although they have not yet been purified.

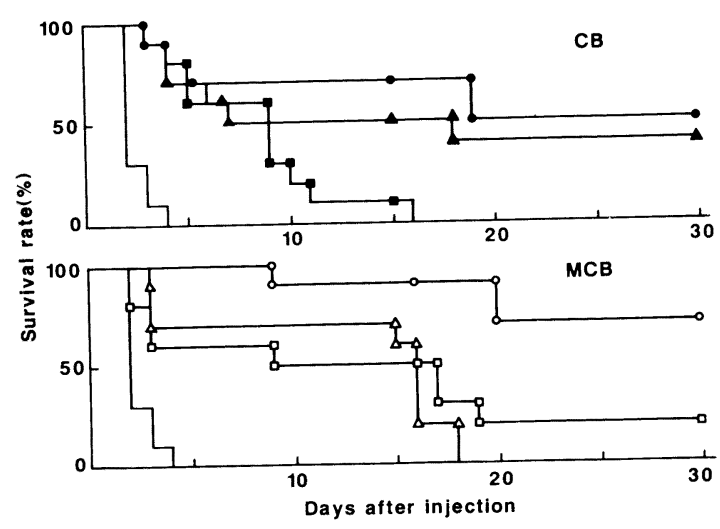

Fig. 1. Protection activity induced by $\mathrm{CB}$ and MCB against systemic Candida albicans infection in mice. Ten DDY mice were used in each group. CB: (- control, - $0.1 \mathrm{mg} / \mathrm{mouse}, 0.5$ $\mathrm{mg} /$ mouse, $\boldsymbol{\Delta}-\boldsymbol{\Delta} 1.0 \mathrm{mg} / \mathrm{mouse})$

MCB: ( - control, $\square-\square 0.1 \mathrm{mg} /$ mouse, $\bigcirc-\bigcirc$ $0.5 \mathrm{mg} / \mathrm{mouse}, \triangle-\triangle 1.0 \mathrm{mg} / \mathrm{mouse})$

Mitogenicity of CB: Since $C B$ was found to be one of the active BRMs against the infection, various immunomodulating activities of $\mathrm{CB}$ were studied. First, mitogenic responses to $\mathrm{CB}$ were detyermined by the enumeration of ${ }^{3} \mathrm{H}$-thymidine incorporation into cultured spleen and thymic cells by pulse labeling. Both cell suspensions prepared from DDY mice were cultured with the indicated amount of $C B$ as compared with LPS and Con A. The results are shown in Table 1. Stimulation of mitogenic responses in splenocytes was observed to be dose dependent. Manimum stimulation of thy. midine uptake was seen with $5.0 \mu \mathrm{g}$ of $\mathrm{CB}$ per $0.2 \mathrm{ml}$ well. However, throughout the studies, the mitogenic response with $\mathrm{CB}$ was somewhat lower than those of LPS and Con A. On the other hand, no mitogenic activity with thymocytes was observed. Time course of mitogenic responses with the spleen cells induced by $5.0 \mu \mathrm{g}$ of CB was studied and compared with that of LPS (Fig. 2). Mitogenic index increased with time, reached maximum at day 2 and then decreased. The incorporation profiles of thymidine were similar to those of LPS. These results indicate that $\mathrm{CB}$ has B-cell mitogenicity.

Effect of $\mathrm{CB}$ on antibody formation: Antibody formation after $\mathrm{CB}$ treatment in mice was determined using a PFC assay method with the spleen cells. DDY mice were immunized intraperitoneally with $1 \times 10^{7}$ $\mathrm{SRBC}$ and concomitantly given intraperitoneal injections of $0.5,1.0,2.0$ and $5.0 \mathrm{mg} /$ mouse of $\mathrm{CB}$. Four days later, the number of anti-SRBC IgM forming cells in the spleen was determined. As shown in Table 2, a marked enhancement of PFC numbers in the spleen was observed in groups of mice treated with 1.0 to 5.0 
Table 1. Mitogenic responses of $\mathrm{CB}$ to lymphocytes from DDY mice

\begin{tabular}{|c|c|c|c|}
\hline Cell cultured & Sample ( $\mu \mathrm{g} /$ well $)$ & $\begin{array}{l}{\left[{ }^{3} \mathrm{H}\right] \text { Thymidine uptake }} \\
(\text { Mean cpm } \pm \text { S.D. })^{* *}\end{array}$ & Significance $(\mathrm{p})^{* *}$ \\
\hline \multirow[t]{6}{*}{ Thymocyte* } & None & $585.3 \pm 113.5$ & \\
\hline & Con A $(2.0)$ & $44913.0 \pm 1159.1$ & $<0.001$ \\
\hline & $(10.0)$ & $1089.3 \pm 128.2$ & $<0.1$ \\
\hline & $(1.0)$ & $306.3 \pm 42.6$ & n.s. \\
\hline & $(5.0)$ & $424.3 \pm \quad 7.0$ & n.s. \\
\hline & $(10.0)$ & $619.0 \pm 101.8$ & n.s. \\
\hline \multirow[t]{6}{*}{ Splenocyte* } & None & $5517.3 \pm 923.5$ & \\
\hline & Con A $(2.0)$ & $31823.3 \pm 881.1$ & $<0.005$ \\
\hline & $(10.0)$ & $39741.6 \pm 1181.1$ & $<0.001$ \\
\hline & $(1.0)$ & $9244.0 \pm 1396.4$ & n.s. \\
\hline & $(5.0)$ & $1722.46 \pm 1554.7$ & $<0.01$ \\
\hline & $(10.0)$ & $16701.3 \pm 846.3$ & $<0.01$ \\
\hline
\end{tabular}

*Thymocytes or splenocytes were cultured with the indicated doses of Con A, LPS and CB for 2 days in microtiter plates at cell density of $1 \times 10^{6}$ cells $/ \mathrm{ml}$ in a total volume of $0.2 \mathrm{ml}$. After 2 days, incorporation of $\left[{ }^{3} \mathrm{H}\right]$ thymidine was determined.

****Mean cpm \pm standard deviation.

***n.s. : not significant. Statistically different from control at the indicated $p$ values.

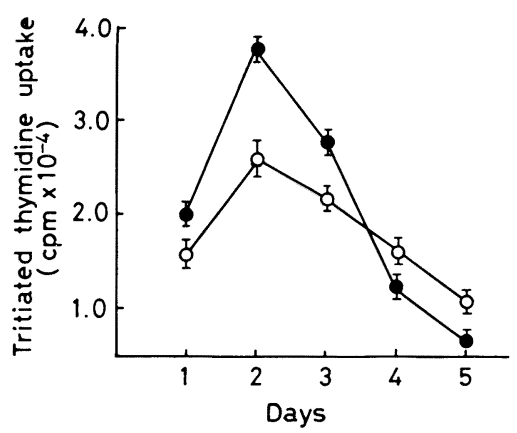

Fig. 2. Kinetics of mitogenic responses of splenocytes to $\mathrm{CB}$. The spleen cells were cultured for 2 days in microtiter plate at a density of $1 \times 10^{6}$ cells/ml with $5 \mu \mathrm{g}$ of $\mathrm{CB}(\bigcirc)$ or $10 \mu \mathrm{g}$ of $\operatorname{LPS}(\bullet)$. $\left[{ }^{3} \mathrm{H}\right]$ Thymidine was added to the culture and after $4 \mathrm{hr}$ incubation, incorporaion ratio of the activities were determined.

$\mathrm{mg} /$ mouse of $\mathrm{CB}$ : the maximum dose was $2.0 \mathrm{mg} /$ mouse and the numbers of PFC declined with the dose of 5.0 $\mathrm{mg}$ /mouse.

Delayed-type footpad reaction: When delayedtype footpad swelling was measured with $\mathrm{CB}$ doses ranging from 0.1 to $10.0 \mathrm{mg}$, a slight increase (statistically significant) in swelling was observed with doses from 1.0 to 5.0 (data not shown).

Time course of NK cell and macrophage activity: Activities of macrophages and NK cell after $\mathrm{CB}$ treatment were studied and the results are shown in Fig. 3. Maximum NK cell activity of spleen cells was observed on day 3 and then decreased rapidly. Macrophage activity of PEC, meanwhile, gradually increased and attained maximum on day 9 to 10 .

Effect on phagocytic activity by macrophage: To further characterize macrophage activation, phagocytic activity was measured as an index of macrophage activation. As shown in Table 3, when DDY mice were given an intraperitoneal injection of $1 \mathrm{mg} /$ mouse of $\mathrm{CB}$, phagocytic activity of macrophages was significantly enhanced and the increase was three times higher than that of control.

IFN production: In the above experiments, we demonstrated the high stimulation of macrophage and NK cell functions. Since macrophage and NK cell have been reported to be stimulated by IFN, we attempted to determine the IFN inducing activity of CB. When DDY mice were given $\mathrm{CB}$ intraperitoneally at doses of 0.1 to $10 \mathrm{mg} /$ mouse, high titers of IFN were observed. Optimum CB dose for the IFN production was $1 \mathrm{mg} /$ mouse as shown in Fig. 4. The maximum IFN activity was 2,560 units, while there were only 320 units of IFN titer with a positive control of OK-432. Time course of IFN production is shown in Fig. 5. IFN production occurred as early as $18 \mathrm{hr}$ after administration of $\mathrm{CB}$ and reached a maximum at $24 \mathrm{hr}$. Thereafter, IFN activity fell rapidly and returned to a normal level within 7 days. 
Table 2. Adjuvant effect of $\mathrm{CB}$ on antibody response to SRBC

\begin{tabular}{cccc}
\hline Stimulant & CB dose $(\mathrm{mg} / \text { mouse })^{*}$ & $\begin{array}{c}\text { Anti-SRBC PFC/spleen } \\
(\text { mean PFC } \pm \text { S.D. })^{* *}\end{array}$ & Significance $(p)^{* * *}$ \\
\hline SRBC only & 0 & $61213 \pm 3882$ & \\
SRBC +CB & 0.5 & $81082 \pm 7226$ & n.s. \\
" & 1.0 & $190492 \pm 1445$ & $<0.005$ \\
" & 2.0 & $275569 \pm 5336$ & $<0.005$ \\
" & 5.0 & $169655 \pm 846$ & $<0.005$ \\
\hline
\end{tabular}

*Five male DDY mice were immunized intraperitoneally with $1 \times 10^{7} \mathrm{SRBC}$ and treated with the indicated doses of $\mathrm{CB}$ at the same time (on day 0 ). Four days later (on day 4), anti-SRBC antibody forming cells were determined as a hemolytic plaque.

**Mean PFC number in the spleen cells \pm standard deviation.

***n.s. : not significant. Statistically different from control at the indicated $p$ values.

Table 3. Phagocytic acitivity of macrophages from CB treated DDY mice

\begin{tabular}{lcc}
\hline \multicolumn{1}{c}{ Treatment regimen* } & $\begin{array}{c}\text { \%Macrophage } \\
\text { engulfing SRBC } \\
\text { (Mean } \pm \text { S.D. })^{* * *}\end{array}$ & $\begin{array}{c}\text { SRBC/macrophage** } \\
(\text { Mean } \pm \text { S.D. })^{* * *}\end{array}$ \\
\hline Control & $44.4 \pm 5.3$ & $151.0 \pm 28.7$ \\
CB $(1.0 \mathrm{mg} /$ mouse $\times 3$ days $)$ & $80.2 \pm 6.7^{* * * *}$ & $421.0 \pm 80.7^{* * * *}$ \\
\hline
\end{tabular}

${ }^{*} \mathrm{CB}$ was injected intraperitoneally for 3 consecutive days (days $-3,-2$ and -

1 ,), and after 2 days (on day 2), peritoneal macrophages (PEC) were harvested. Sheep erythrocytes (SRBC) coated with anti-SRBC antiserum were used.

**Number of SRBC found in 100 macrophages including both engulfing and non-engulfing cells.

***Mean number \pm standard deviation.

$* * * *$ Statistically different from control at $p<0.05$.

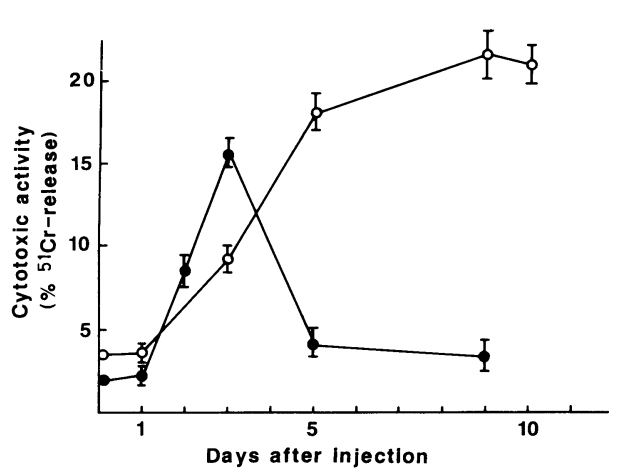

Fig. 3. Time course of NK-cell and macrophage activities after $\mathrm{CB}$ treatment. Macrophage $\mathrm{O} O$ $\bigcirc)$ and NK cell $(\bullet-\bullet)$ activities (mean \pm standard deviation).

\section{Production and characterization of interferon in} different mouse strains: In order to determine the response of different mouse strains to $\mathrm{CB}, 6$ strains of mice, $\mathrm{C} 57 \mathrm{BL} / 6, \mathrm{C} 3 \mathrm{H} / \mathrm{He}, \mathrm{Balb} / \mathrm{c}, \mathrm{BDF}_{1}$, ICR and DDY mice were used. These different mouse strains were

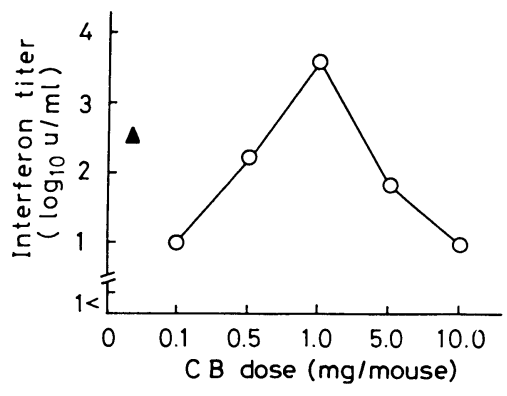

Fig. 4. Production of IFN in DDY mice by various doses of CB. Pooled sera were obtained from DDY mice $24 \mathrm{hr}$ after intraperitoneal injection of various doses of $\mathrm{CB}(\mathrm{O})$. OK-432 ( $\mathbf{\Lambda})$ was used as a reference. Five mice were used in each dose.

treated with CB and IFN titers at $24 \mathrm{hr}$ were determined. As shown in Table 4, there were significant differences in IFN production among the mouse strains tested. The highest response was observed with DDY and $\mathrm{BDF}_{1}$, followed by C57BL/ 6 and ICR, and the lowest response 
Table 4. Induction and characterization of IFN induced by $\mathrm{CB}$ treatment in various mouse strains

\begin{tabular}{lcrrcc}
\hline \multirow{2}{*}{ Mouse strain } & \multicolumn{4}{c}{ IFN titers(unit) } \\
\cline { 2 - 6 } & \multicolumn{2}{c}{ IFN produced* } & \multicolumn{2}{c}{ Residual } & IFN titer(unit/ml)after tereatment with \\
& Control & CB & PH 2 & Heat & Anti- $\alpha / \beta^{* *}$ \\
\hline DDY & $<10$ & 2560 & $<10$ & $<10$ & 2560 \\
$\mathrm{C} 57 \mathrm{BL} / 6$ & 20 & 1280 & $<10$ & $<10$ & NT \\
$\mathrm{C} 3 \mathrm{H} / \mathrm{He}$ & 40 & 320 & $<10$ & $<10$ & NT \\
$\mathrm{ICR}$ & 10 & 1280 & $<10$ & $<10$ & NT \\
$\mathrm{Balb} / \mathrm{c}$ & $<10$ & 640 & $<10$ & $<10$ & NT \\
$\mathrm{BDF} 1$ & $<10$ & 1280 & $<10$ & $<10$ & NT \\
\hline
\end{tabular}

*Pooled sera were obtained from 6 to 8 DDY mice from each group $24 \mathrm{hr}$ after intraperitoneal injection of $1.0 \mathrm{mg} / \mathrm{mouse}$ of $\mathrm{CB}$.

Each treated serum was assayed immediately for the antiviral activity.

${ }^{* *}$ Result after neutralization by antiserum.

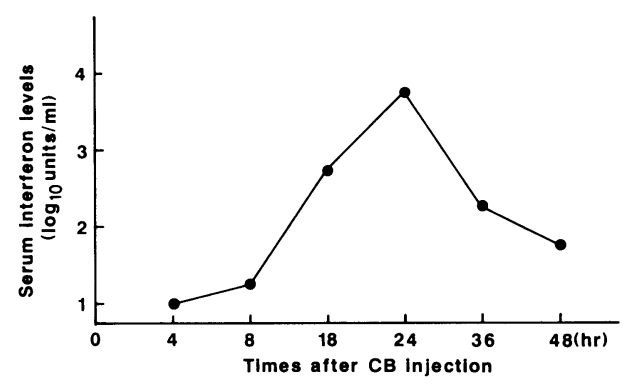

Fig. 5. Time course of IFN production in DDY mice. Five mice were used in each experiment.

was observed with $\mathrm{C} 3 \mathrm{H} / \mathrm{He}$ and $\mathrm{Balb} / \mathrm{c}$ mice. The difference was among them more than 4 fold. In order to determine the type of IFN induced by $\mathrm{CB}$, various physicochemical properties were compared. IFN activity was diminished by dialysis against $0.1 \mathrm{M}$ glycine- $\mathrm{HCl}$ buffer ( $\mathrm{pH} 2.0$ ) for $24 \mathrm{hr}$ at $4^{\circ} \mathrm{C}$ or incubation at $56^{\circ} \mathrm{C}$ for $60 \mathrm{~min}$, and not decreased by treatment of anti-IFN $(\alpha / \beta)$, indicating that the present major IFN activity is similar to the immune-type interferon, IFN- $\gamma$ reported by Falcoff ${ }^{13)}$.

Effect of recombinant IFN $\alpha-(A / D)$ on $C$. albicans infection in mice: Since it was found that a high titer of IFNs is produced after CB treatment in DDY mice, protection activity of recombinant IFN $\alpha-\mathrm{A} / \mathrm{D}$ agaisnt Candida infection was studied. As shown in Fig. 6, IFN $\alpha-\mathrm{A} / \mathrm{D}$ showed a significant protection activity when administered intravenously. These data suggest the important role of IFNs as effectors in the protection against Candida infection in mice.

\section{DISUCSSION}

In the present studies, we first confirmed that $\mathrm{CB}$ has

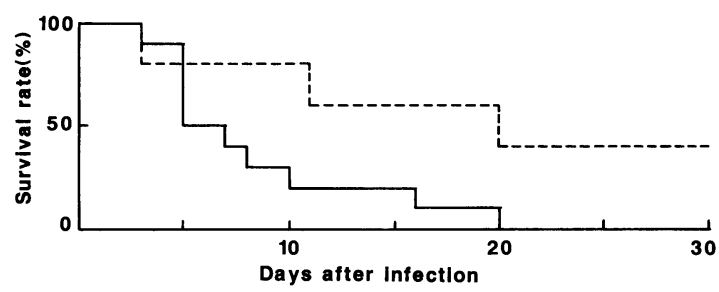

Fig. 6. Effect of recombinant IFN $\alpha$-(A/D) on Candida albicans infection in mice. IFN $\left(1 \times 10^{4}\right.$ units of IFN $\alpha-\mathrm{A} / \mathrm{D}$ ) were administered intravenously into the tail vein of DDY mice. Control ( - ) and interferon treated group (...).

various immunomodulating activities which have already been reported in various bacterial BRMs such as bacillus Calmette-Guerin (BCG) ${ }^{14)}$, $\mathrm{PSK}^{15)}$, MDP ${ }^{16)}$, $\mathrm{LPS}^{17)}$ and $\mathrm{OK}-432^{18)}$. However, it has been reported that there exist subtle differences in immunomodulating activity among these bacterial preparations ${ }^{19}$. Furthermore, living spores of $C$. butyricum have been used clinically over the past 40 years in Japan and their clinical safety has been confirmed ${ }^{2}$. Therefore, $C B$ is considered worth of further evaluation as an active BRM for anti-candida therapy, although detailed studies are necessary for its application.

Most BRMs can be classified into two groups due to their immunomodulating activities: Poly ICLC and MVE-2 belong to one group and have ability to activate macrophage. Thymosin fraction 5 belongs to the other and these immunomodulators have an apparent direct effect on T-cells ${ }^{19}$. According to this definition, CB might belong to the former group, because it showed only a weak delayed-type hypersensitivity and mitogenic response with thymocytes.

Throughout the present studies, we used mainly 
heat-killed whole cell preparation of C. butyricum (CB). However, we were able to demonstrate that the active principles of $\mathrm{CB}$ are extractable with organic solvent. MCB fraction is partially purified by Sephadex LH-20 column chromatography. In our preiliminary studies, $\mathrm{MCB}$ was found to be a potent NK-cell activator and to have B-cell mitogenic activity. Further purification studies are now in progress.

Since some bacterial preparations have been also reported to have IFN inducing activity both in vitro and in vivo ${ }^{20)}$, we attempted to identify the antiviral principle. The present experiments showed that IFNs produced by $\mathrm{CB}$ treatment is mainly $\gamma$-type.

With reference to effectors, IFNs were considered to have the most potential as candidates with anti-candida activity in mice. Actually it was found that recombinant IFN $\alpha-\mathrm{A} / \mathrm{D}$ showed a protection activity when administered intravenously. Although IFN produced by $\mathrm{CB}$ was mainly $\gamma$-type, production of $\alpha$-and/or $\beta$-type IFN(s) by $\mathrm{CB}$ could not be excluded. Recently Brummer $e t$ al. ${ }^{21}$ ) and Kagaya et al ${ }^{22)}$ reported in vitro and in vivo anticandida activity of recombinant IFN- $\gamma$.

Therefore further detail studies on the role of each type of IFNs against the Candida infection are necessary. However, we found that lentinan also exhibits strong protection against $C$. albicans infection (Kaneda $e t$ $a l$., manuscript in preparation). As already reported ${ }^{23)}$, and we also confirmend it, production of IFN by lentinan is very weak or negligible. Therefore, it is reasonable to consider that some other factors such as interleukins, in the present model might be playing a role as effectors to protect mice against the infection.

We also found that IFN production by $\mathrm{CB}$ is strain dependent and $\mathrm{DDY}$ or $\mathrm{BDF}_{1}$ mice were high responders in IFN production by $\mathrm{CB}$. Therefore, the experimental model using DDY mice and $\mathrm{CB}$ vaccine is considered a suitable tool for analysis of the protection mechanisms induced by $\mathrm{CB}$ treatment.

\section{Acknowledgements}

This work was supported by a grant-in-aid from the Ministry of Education, Science and Culture of Japan.

\section{References}

1) Miyairi, K.: Effect of $\mathrm{pH}$ on the growth of intestinal microflora (in Japanese). J. Chiba Med. Soc., 13: 1102-1157, 1953.

2) Kobayashi, S., Tanami, J. and Kitamura, T.: Effect of oral administration of Miyairisan, a preparation composed of Clostrodium butyricum spores, on the intestinal bacterial flora of infants. J. Chiba Med. Soc., 44: 186-192, 1986.

3) Thomas, E.R. and Galgiani, J.N.: Activity of fluconazole (UK49, 853) and ketoconazole against
Candida albicans in vitro and in vivo. Antimicrob. Agents and Chemother, 30: 418-422, 1986.

4) Maeda, A., Ishii, K., Tanaka, M., Mikami, Y. and Arai, T.: KM1, a bacteriophage of Clostridium butyricum. J. Gen. Microbiol., 132: 2271-2275, 1986.

5) Kumazawa, Y., Mizunoe, K. and Otsuka, Y.: Immunostimulating polysaccharide separated from hot water extract of Angelica acutiloba Kitagawa (Yamato Tohki). Immunology, 47: 75-83, 1982.

6) Yoshikai, Y., Miyake, S., Matsumoto, T., Nomoto, L. and Takeya, K.: Effect of stimulation and blockade of mononuclear phagocyte system on the delayed footpad reaction to SRBC in mice. Immunology, 38: 577-583, 1979.

7) Cunningham, A.J. and Szenberg, A.: Further improvement in the plaque technique for detecting single antibody-forming cells. Immunology, 14: 599-601, 1968.

8) Kuwata, T., Oda, T., Sekiya, S. and Morinaga, N.: Characteristics of a human cell line successively transformed by Rous sarcoma virus and simian virus 40. J. Natl. Cancer Inst., 56: 919-926, 1976.

9) Armstrong, J.A.: Semi-micro, dye-binding assay for rabbit interferon. Appl. Microbiol., 21: 723-726, 1971.

10) Kawada, Y.: An analysis of neutralization reaction of interferon by antibody: A proposal on the expression of neutralization titer. J. Interferon Res., 1: 61-70, 1980.

11) Yamamoto, Y. and Kawada, Y.: Antigenicity of mouse interferon distinct antigenicity of the two Lcell interferon species. Virology, 103: 80-88, 1980.

12) Kato, I., Yokokura, T. and Mutai, M.: Macrophage activation by Lactobacillus case $i$ in mice. Microbiol. Immunol., 27: 611-618, 1983.

13) Falcoff, R.: Some properties of virus and immuneinduced human lymphocyte interferons. J Gen. Virol., 16: 251-253, 1972.

14) Sher, N.A., Chaparas, L.E., Greenberg, and Bernard, S.: Effect of BCG, Corynebacterium parvum and methanol-extraction residue in the reduction of mortality from Staphylococcus aureus and Candida albicare infection in immunosuppressed mice. Infect. Immunol., 12: 1325-1330, 1975.

15) Mayer, P. and Drews, J.: The effect of a proteinbound polysaccharide from Coriolus versicolor on immunological parameters and experimental infections in mice. Infection, 8: 13-21, 1980.

16) Chedled, L., Parant, M., Parant, F., Lofrancier, P., Choay, J. and Lederer, E.: Enhancement of nonspecific immunity to Klebsiella pneumoniae infection by a synthetic immunoadjuvant ( $\mathrm{N}$-acetyl-muramyl- 
L-alanyl-D-isoglutamine) and several analogs. Proc. Natl. Acad. Sci. USA. 74: 2089-2093, 1977.

17) Kotani, S., Takada, H., Tsujimoto, M., Ogawa, T., Takahashi, I., Ikeda, T., Otsuka, K., Shimauchi, H., Kasai, N., Mashimo, J., Nagao, S., Tanaka, A., Tanaka, S., Harada, K., Nagaki, K., Kitamura, H., Shiba, T., Kusumoto, S., Imoto, M. and Yoshimura, H.: Synthetic lipid A with endotoxic and related biological activities comparable to those of a natural lipid A from an Escherichia coli Re-mutant. Infect. Immun., 49: 225-237, 1985.

18) Shiraishi, A., Mikami, Y. and Arai, T.: Protective effect of OK-432 (a streptococcal preparation) on experimental candidiasis. Microbiol. Immunol., 23: 549-554, 1979.

19) Talmadge, J.E. and Herberman, R.B.: The preclinical screening laboratory: Evaluation of immunomodulatory and therapeutic properties of biological response modifiers. Cancer Treatment Rept., 70:
171-182, 1986.

20) Yamaguchi, T., Kuroda, Y., Saito, M., Ebina, T., Hoshino, F. and Ishida, N.: Immune interferon producing TH69, a lyophilized preparation of Strep. tococcus faecalis in murine spleen cell cultures. Microbiol. Immunol., 38: 601-610, 1984.

21) Brummer, E., Morrison, C.J. and Stevens, D.A.: Recombinant and natural gamma-interferon activation of macrophages in vitro: Different dose requirements for induction of killing activity against phagocytizable and nonphagocytizable fungi. Infect. Immun., 49: 724-730, 1985.

22) Kagaya, K., Miyagawa, Y., Watanabe, K. and Fukazawa, Y.: 30th Annual Meeting of Jap. Soc. for Medical Mycology, Akita, 1987.

23) Hamuro, J. and Chihara, G.: Lentian, a T-celloriented immunopotentiator. In Immune Modulation Agents and Their Mechanisms: Marcel Dekker Inc., New York., p. 409-435, 1982. 